\title{
Impact of Abnormal Serum Electrolyte Levels and Acid-Base Disorders on Clinical Outcomes among Maintenance Hemodialysis Patients
}

\author{
Vricksha Guttee ${ }^{1}$, Yuxin Nie ${ }^{1,2}$, Yimei Wang1,2,3,4, Xiaoqiang Ding1,2,3,4 \\ ${ }^{1}$ Division of Nephrology, Zhongshan Hospital, Shanghai Medical College, Fudan University, Shanghai, China \\ ${ }^{2}$ Shanghai Institute of Kidney Disease and Dialysis, Shanghai, China \\ ${ }^{3}$ Key Laboratory of Kidney and Blood Purification of Shanghai, Shanghai, China \\ ${ }^{4}$ Quality Control Center of Dialysis, Shanghai, China \\ Email:vricksha@hotmail.com
}

How to cite this paper: Guttee, V., Nie, Y.X., Wang, Y.M. and Ding, X.Q. (2017) Impact of Abnormal Serum Electrolyte Levels and Acid-Base Disorders on Clinical Outcomes among Maintenance Hemodialysis Patients. Open Access Library Journal, 4: e3623.

https://doi.org/10.4236/oalib.1103623

Received: April 20, 2017

Accepted: May 13, 2017

Published: May 16, 2017

Copyright $\odot 2017$ by authors and Open Access Library Inc.

This work is licensed under the Creative Commons Attribution International License (CC BY 4.0).

http://creativecommons.org/licenses/by/4.0/

\begin{abstract}
There has been a notable rise in the number of patients diagnosed with chronic kidney disease (CKD) over the years across the world, with most cases subsequently leading to end-stage renal failure. Hemodialysis (HD) remains one of the main treatments for end-stage renal disease (ESRD) worldwide. Despite improvements in dialysis care, the mortality of patients with ESRD on maintenance hemodialysis is persistently high. Abnormal levels of serum electrolytes, pre- and post-dialysis, and acid-base disorders have a crucial influence on clinical outcomes in HD patients. In this review, we aim to discuss the different effects that serum electrolyte levels have on the prognosis of patients on maintenance hemodialysis, particularly sodium, potassium, magnesium, phosphorus and bicarbonate.
\end{abstract}

\section{Subject Areas}

Internal Medicine, Nephrology

\section{Keywords}

Chronic Kidney Disease, End-Stage Renal Disease, Hemodialysis, Electrolyte, Acid-Base Disorder

\section{Introduction}

The number of patients diagnosed with chronic kidney disease (CKD) has increased to a great extent over the years worldwide, with most cases subsequently leading to end-stage renal failure [1]. End-stage renal disease (ESRD) is the irre- 
versible deterioration of renal function to an extent that survival is greatly shortened without renal replacement therapy (RRT), either by dialysis or transplantation. The 2016 US Renal Data System (USRDS) Annual Data Report showed the estimated CKD (stages 1 - 5) prevalence in the United States was $14.8 \%$ in 2014 and 120,688 new patients with ESRD [2] while another study demonstrated the prevalence of CKD among middle aged and elderly patients in China to be $11.5 \%$ [3]. Hemodialysis (HD) remains one of the main treatments for ESRD across the world. The goal of HD is to replace the kidney's excretory function, especially preventing or improving fluid and electrolyte disorders such as fluid overload, hypo-/hypernatremia, hypo-/hyperkalemia, hypo-/hypercalcemia, hypo-/hyperphosphatemia, metabolic acidosis and alkalosis.

\section{Prevalence of Serum Electrolytes Abnormalities}

A few studies have shown the prevalence of hyponatremia to be higher than that of hypernatremia among maintenance hemodialysis (MHD) patients [4] [5]. In a study of 1549 MHD patients, Waikar et al. found the prevalence of hyponatremia to be $29.3 \%$ while that of hypernatremia was $18.9 \%$ [5]. However, in another study of 11,500 patients from the Dialysis Outcomes and Practice Patterns Study (DOPPS), Hecking et al. found the prevalence of mean pre-dialysis serum sodium level lower than $137 \mathrm{mmol} / \mathrm{L}$ to be $27 \%$ and that of mean pre-dialysis serum sodium level higher than or equals to $140 \mathrm{mmol} / \mathrm{L}$ to be $31 \%$ [6]. Hyponatremia is a frequently seen electrolyte disorder while hypermagnesemia is also highly prevalent in MHD patients and it tends to be in a higher percentage than hypomagnesemia [7] [8] [9] [10]. In a cohort study of 27,544 MHD patients in the United States, 4729 patients (17.2\%) had hypomagnesemia and 6133 patients (22.3\%) had hypermagnesemia [10].

Hyperphosphatemia is another commonly encountered electrolyte abnormality in MHD patients. In DOPPS I and DOPPS II, the prevalence of hypophosphatemia among hemodialysis patients was $7.6 \%$ and $9.0 \%$ respectively and that of hyperphosphatemia was $51.6 \%$ and $46.7 \%$ respectively [11]. Hypercalcemia also tended to be more prevalent than hypocalcemia in MHD patients as shown in some studies conducted in Japan and the US [12] [13] [14] (Table 1). A higher number of HD patients tended to have metabolic acidosis than metabolic alkalosis. In a study by Bommer et al. using data from DOPPS, there were 53.0\% patients who had metabolic acidosis while only $19.7 \%$ had metabolic alkalosis [15]. The prevalence of electrolyte imbalances and acid-base disorders in American and Japanese MHD patients are summarized in Table 1.

\section{Sodium Disorders}

Preserving sodium balance (extracellular fluid volume) is an important task of RRT. While HD is intermittent and salt and fluid intake is a continued process during interdialytic period, maintaining this balance is a difficult task [19]. Hyponatremia (serum sodium concentration $<135 \mathrm{mmol} / \mathrm{L}$ ) [5] is a common electrolyte disorder in patients with ESRD and an increasing number of studies 
Table 1. Prevalence of electrolyte imbalances and acid-base disorders in American and Japanese MHD patients.

\begin{tabular}{|c|c|c|c|c|c|}
\hline References & Year & Type & $\begin{array}{c}\text { Number } \\
\text { of }\end{array}$ & \multicolumn{2}{|c|}{ Electrolyte disorder } \\
\hline \multirow{3}{*}{$\begin{array}{l}\text { C.M Rhee } \\
\text { et al. [4] }\end{array}$} & \multirow{3}{*}{2015 (USA) } & \multirow{3}{*}{$\begin{array}{c}\text { Observational } \\
\text { study }\end{array}$} & \multirow{3}{*}{27,180} & $\begin{array}{l}\text { Hyponatremia } \\
(<135 \mathrm{mmol} / \mathrm{L})\end{array}$ & $\begin{array}{l}\text { Hypernatremia } \\
(>145 \mathrm{mmol} / \mathrm{L})\end{array}$ \\
\hline & & & & $1939(7.1 \%)$ & $549(2.0 \%)$ \\
\hline & & & & $\begin{array}{c}\text { Hypokalemia } \\
(<3.5 \mathrm{mmol} / \mathrm{L})\end{array}$ & $\begin{array}{l}\text { Hyperkalemia } \\
(>5.5 \mathrm{mmol} / \mathrm{L})\end{array}$ \\
\hline \multirow[t]{2}{*}{$\begin{array}{l}\text { Kovesdy } \\
\text { et al. [16] }\end{array}$} & \multirow[t]{2}{*}{2007 (USA) } & \multirow[t]{2}{*}{$\begin{array}{c}\text { Observational } \\
\text { study }\end{array}$} & \multirow[t]{2}{*}{74,219} & $6617(8.9 \%)$ & $9062(12.2 \%)$ \\
\hline & & & & $\begin{array}{c}\text { Hypomagnesemia } \\
(<0.74 \mathrm{mmol} / \mathrm{L})\end{array}$ & $\begin{array}{c}\text { Hypermagnesemia } \\
(\geq 1.15 \mathrm{mmol} / \mathrm{L})\end{array}$ \\
\hline \multirow[t]{2}{*}{$\begin{array}{l}\text { Y. Sakaguchi } \\
\text { et al. [17] }\end{array}$} & \multirow[t]{2}{*}{2013 (Japan) } & \multirow[t]{2}{*}{$\begin{array}{l}\text { Observational } \\
\text { cohort Study }\end{array}$} & \multirow[t]{2}{*}{142,555} & $28,764(20.1 \%)$ & $46,249(32.4 \%)$ \\
\hline & & & & $\begin{array}{l}\text { Hypophosphatemia } \\
(<0.9 \mathrm{mmol} / \mathrm{L})\end{array}$ & $\begin{array}{l}\text { Hyperphosphatemia } \\
(>1.34 \mathrm{mmol} / \mathrm{L})\end{array}$ \\
\hline \multirow[t]{2}{*}{$\begin{array}{c}\text { Nakai et al. } \\
{[12]}\end{array}$} & \multirow[t]{2}{*}{2008 (Japan) } & \multirow[t]{2}{*}{$\begin{array}{c}\text { Cross-sectional } \\
\text { study }\end{array}$} & \multirow[t]{2}{*}{27,404} & $787(2.9 \%)$ & $23,855(87.0 \%)$ \\
\hline & & & & $\begin{array}{l}\text { Hypocalcemia } \\
(<2.15 \mathrm{mmol} / \mathrm{L})\end{array}$ & $\begin{array}{l}\text { Hypercalcemia } \\
(>2.55 \mathrm{mmol} / \mathrm{L})\end{array}$ \\
\hline \multirow[t]{2}{*}{$\begin{array}{c}\text { Rivara } \\
\text { et al. [14] }\end{array}$} & \multirow[t]{2}{*}{2015 (USA) } & \multirow[t]{2}{*}{$\begin{array}{l}\text { Observational } \\
\text { cohort study }\end{array}$} & \multirow[t]{2}{*}{118,955} & $5985(5.03 \%)$ & $12,844(10.7 \%)$ \\
\hline & & & & $\begin{array}{l}\text { Low serum } \\
\text { bicarbonate } \\
(<23 \mathrm{mmol} / \mathrm{L})\end{array}$ & $\begin{array}{l}\text { High serum } \\
\text { bicarbonate } \\
(\geq 27 \mathrm{mmol} / \mathrm{L})\end{array}$ \\
\hline $\begin{array}{c}\text { Wu et al. } \\
\quad[18]\end{array}$ & 2005 (USA) & $\begin{array}{l}\text { Observational } \\
\text { Cohort Study }\end{array}$ & 56,386 & $35,970(63.8 \%)$ & $2207(3.9 \%)$ \\
\hline
\end{tabular}

showed that low serum sodium is an independent predictor of mortality and has negative health consequences (Table 2).

In their studies, Waikar et al. showed that among MHD patients without residual renal function, lower serum sodium concentration was associated with a higher mortality, even after adjustment for demographic, clinical, laboratory, and dialysis-specific covariates [5]. Mandai et al., in an observational cohort study including $332 \mathrm{MHD}$ patients, showed that those with lower serum sodium had an increased risk for infection-related hospitalization [20].

It is important for physicians to prescribe the dialysate sodium concentration according to patients' pre-dialysis serum sodium levels. In a cohort study of 2272 patients on thrice-weekly HD treatment, when using low sodium dialysate $(<140$ $\mathrm{mmol} / \mathrm{L}$ ), patients with higher pre-dialysis sodium concentration showed better survival than those with lower pre-dialysis sodium concentration [21] while 
Table 2. Low serum sodium concentration indicates negative outcomes in MHD patients in US and Japan.

\begin{tabular}{ccccccc}
\hline Authors & Year & Type of study & $\begin{array}{c}\text { Number of } \\
\text { subjects }\end{array}$ & Outcomes & HR & 95\% CI \\
\hline Waikar [5] & 2011 & $\begin{array}{c}\text { Randomized } \\
\text { controlled } \\
\text { trial }\end{array}$ & 1549 & Risk of death & 0.81 & $0.72-0.91$ \\
$\begin{array}{c}\text { Mandai } \\
{[20]}\end{array}$ & 2013 & $\begin{array}{c}\text { Observational } \\
\text { study }\end{array}$ & 332 & $\begin{array}{c}\text { Infection-related } \\
\text { hospitalization }\end{array}$ & 2.36 & $1.10-5.04$ \\
$\begin{array}{c}\text { C. M. Rhee } \\
{[4]}\end{array}$ & 2015 & $\begin{array}{c}\text { Observational } \\
\text { study }\end{array}$ & 27,180 & Mortality & 1.45 & $1.26-1.67$ \\
\hline
\end{tabular}

Abbreviations: HR: Hazard risk; CI: Confidence interval.

C. M. Rhee et al., in time-varying analyses, found a U-shaped association between pre-dialysis serum sodium levels and all-cause mortality [4].

Low serum sodium level is not only associated with higher mortality but has also been found to be related to other electrolyte disorders, such as hypercalcemia. In a large prospective cohort of incident HD patients, Nigwekar et al. showed that hyponatremia is also associated with bone abnormalities. At the time of initiation to dialysis therapy, patients with hyponatremia were noted to have higher prevalences of hypercalcemia $(2.2 \%$ vs. $1.2 \% ; \mathrm{P}=0.02)$, elevated alkaline phosphatase levels ( $20.3 \%$ vs. $15.7 \% ; \mathrm{P}=0.002)$, and hypoparathyroidism ( $27.5 \%$ vs. $20.9 \%$; $<$ 0.001) compared with patients with normal serum sodium levels [22].

The above studies showed that monitoring pre-dialysis serum sodium level is important so as to provide appropriate sodium dialysate prescription for HD patients and also encourage a proper dietary sodium intake, hence improving HD patients' prognosis [23] [24].

\section{Potassium Disorders}

Another complication commonly seen in ESRD patients being given HD treatment is hyperkalemia. MHD patients regularly accumulate potassium during the interdialytic period, therefore removal of potassium $(\mathrm{K})$ is one of the most important functions of chronic HD.

Pre-dialysis hyper- and hypokalemia have been found to be associated with a higher risk of electrocardiogram abnormalities and cardiac death [25] [26] [27] [28]. In a large cohort of MHD patients, Kovesdy et al. found the association of pre-dialysis hyperkalemia with all-cause and cardiovascular mortality after detailed adjustments for potential confounding variables [16]. In a historical cohort of chronic HD patients, Genovesi et al. showed pre-dialysis hyperkalemia to be associated with a 2.7 (CI 95\% 1.3 - 5.8)-fold increase in the risk of sudden death [29]. Also, an increasing risk of sudden cardiac arrest among patients with pre-dialysis serum potassium levels above $5.0 \mathrm{mmol} / \mathrm{L}$ was observed but no advantage of using low potassium dialysate $(<2 \mathrm{mmol} / \mathrm{L})$ was found at any level of serum potassium in a study by Pun et al. [27]. However, hypokalemia is also 
linked to a high mortality rate. According to Hwang et al., HD patients with lower pre-dialysis levels of both serum potassium and serum sodium were associated with an elevated long-term mortality risk [30]. Patients with lower serum potassium and lower serum sodium levels were characterized by hypoalbuminemia and lower normalized protein catabolic rate (nPCR) level. They were also associated with higher high sensitivity C-reactive protein (hs-CRP) level, and more comorbidity. Their study showed that lower levels of both electrolytes were able to predict the worst long-term prognoses, independent of risk factors like diabetes mellitus, age, gender and HD vintage.

Moreover, significant sudden shifts in electrolytes, particularly potassium, and fluid volume that surround a dialysis session act as triggers and can initiate life-threatening arrhythmias in MHD patients, which is closely linked to sudden cardiac death [31] [32] [33]. Electrocardiogram (ECG) measures related to ventricular repolarization such as QT interval dispersion and QT interval prolongation worsen over the course of a dialysis treatment. In a study by Morris et al., these ECG changes have been shown to be influenced by exposure to potassium during HD, and have been independently associated with cardiovascular mortality in dialysis patients [34] [35]. Also, Jadoul et al. found that dialysate with potassium level $<3 \mathrm{mEq} / \mathrm{L}$ was associated with higher sudden death risk, which was most obvious amongst patients with low pre-dialysis serum potassium levels $(<5$ $\mathrm{mEq} / \mathrm{L})[26]$.

Although appropriately prescribed dialysis therapies still are the main way to control hyperkalemia, dietary strategies should also be used to avoid large fluctuations in serum potassium concentration while ensuring adequate nutrition. The potential beneficial impact of alternative dialysis strategies that would ensure better control of potassium imbalance and prevent marked fluctuations in serum potassium concentration should also be considered.

\section{Magnesium Disorders}

Magnesium (Mg) is mainly excreted through the renal system and HD patients may have a normal, increased or decreased level of serum magnesium [36]. Higher level of serum magnesium is mostly associated with better prognoses in MHD patients (Table 3) and it was found to be associated with lower mortality risk in this group of patients in several studies [10] [37]. In Sakaguchi et al.'s cohort study, it was shown that the mortality risk of HD patients with hyperphosphatemia was greatly reduced with increasing serum magnesium [17]. A study in Portugal showed an association between lower magnesium levels and increased cardiovascular risk markers and higher mortality in HD patients [38]. Another study found a strong and inverse association between serum magnesium and all-cause mortality, cardiovascular mortality and sudden death in European HD patients [39]. In a prospective study of Japanese HD patients who had secondary hyperparathyroidism (SHPT) by Kurita et al. demonstrated that relatively low serum magnesium levels were associated with all-cause death (adjusted HR 1.737, 95 CI $1.200-2.512$ for lowest quintiles of serum magnesium 
Table 3. Low serum magnesium levels indicating negative clinical outcomes in HD patients.

\begin{tabular}{|c|c|c|c|c|c|c|}
\hline Authors & $\begin{array}{c}\text { Year } \\
\text { Published }\end{array}$ & $\begin{array}{l}\text { Type of } \\
\text { study }\end{array}$ & $\begin{array}{l}\text { Number } \\
\text { of subjects }\end{array}$ & Outcomes & $\mathrm{HR} / \mathrm{OR}$ & $95 \% \mathrm{CI}$ \\
\hline Sakaguchi [17] & 2014 & $\begin{array}{l}\text { Prospective } \\
\text { cohort study }\end{array}$ & 142,069 & $\begin{array}{l}\text { Increased } \\
\text { mortality }\end{array}$ & OR 0.74 & $0.56-0.97$ \\
\hline Ishimura [37] & 2007 & $\begin{array}{c}\text { Observational } \\
\text { study }\end{array}$ & 553 & $\begin{array}{c}\text { All-cause and } \\
\text { non-CV } \\
\text { mortality }\end{array}$ & $\begin{array}{l}{ }^{*} \mathrm{HR} 0.485 \\
{ }^{\#} \mathrm{HR} 0.388\end{array}$ & $\begin{array}{l}0.241-0.975 \\
0.132-0.769\end{array}$ \\
\hline Lacson [10] & 2015 & $\begin{array}{l}\text { Observational } \\
\text { cohort study }\end{array}$ & 27,544 & Low survival & HR 1.6 & $1.21-1.45$ \\
\hline $\begin{array}{c}\text { João Matias } \\
{[38]}\end{array}$ & 2015 & $\begin{array}{l}\text { Prospective } \\
\text { study }\end{array}$ & 206 & $\begin{array}{c}\text { Increased CV } \\
\text { and all-cause } \\
\text { mortality }\end{array}$ & $\begin{array}{l}{ }^{c} \text { HR } 0.82 \\
{ }^{\star} \text { HR } 0.87\end{array}$ & $\begin{array}{l}0.72-0.95 \\
0.88-0.99\end{array}$ \\
\hline $\begin{array}{c}\text { de Roij van } \\
\text { Zuijdewijn [39] }\end{array}$ & 2015 & $\begin{array}{l}\text { Randomized } \\
\text { controlled trial }\end{array}$ & 365 & $\begin{array}{l}\text { All-cause and } \\
\text { CV mortality. }\end{array}$ & $\begin{array}{l}{ }^{*} \mathrm{HR} 0.85 \\
{ }^{c} \mathrm{HR} 0.73\end{array}$ & $\begin{array}{l}0.77-0.94 \\
0.62-0.85\end{array}$ \\
\hline Kurita [40] & 2015 & $\begin{array}{l}\text { Prospective } \\
\text { study }\end{array}$ & 2185 & $\begin{array}{c}\text { All-cause death } \\
\text { CVD, } \downarrow \text { Alb, } \\
\uparrow \text { CRP. }\end{array}$ & ${ }^{\star} \mathrm{HR} 1.74$ & $1.20-2.51$ \\
\hline
\end{tabular}

Abbreviations: CV: cardiovascular; CVD: cerebrovascular disease; Alb: serum albumin; CRP: C-reactive protein; OR: Odds ratio; HR: hazard risk; $\uparrow$ : Increased; $\downarrow$ : Decreased; *: hazard ratio related to all-cause mortality; \#: hazard ratio related to non-CV mortality; C: hazard ratio related to CV mortality.

and HR 1.675, 95\% CI $1.254-2.238$ for second lowest quintiles). They also showed the positive association between serum magnesium levels and serum potassium levels (for $\mathrm{Mg} \leq 2.3 \mathrm{mg} / \mathrm{dl}$ and $\mathrm{K} \leq 3.5 \mathrm{mEq} / \mathrm{L}$, adjusted odds ratio (AOR) 2.070, 95\% CI $1.349-3.175, \mathrm{P}=0.001$; for $\mathrm{Mg}>3.0 \mathrm{mg} / \mathrm{dl}$ and $\mathrm{K}>6.0$ $\mathrm{mEq} / \mathrm{L}, \mathrm{AOR} 2.526,95 \%$ CI 1.907 - 3.347, P < 0.001) among HD patients. Moreover, they noted that relatively low serum magnesium levels and the presence of atrial fibrillation (AOR 1.711, 95\% CI $1.209-2.421, \mathrm{P}=0.002$ ) and cerebrovascular disease ( $\mathrm{AOR}=1.336,95 \% \mathrm{CI} 1.035-1.725, \mathrm{P}=0.026$ ) are correlated [40].

Recent results have indicated that low intradialytic serum magnesium level was associated with hypotensive episodes during HD [36] [41] [42]. Also, ESRD patients with low serum magnesium level were observed to have a higher and faster rate of vascular calcification [43] [44] [45]. Moreover, lower serum magnesium was associated with higher pulse pressure, left ventricular mass index and the presence of more vascular calcifications [38].

Serum magnesium also has an important influence on other metabolic processes in MHD patients. Several studies have found significant positive association of serum magnesium levels with dyslipidemia in HD patients [46] [47] [48]. However, in another study of $103 \mathrm{HD}$ patients, no relation was found between serum magnesium level and atherogenic lipids [49]. In a prospective study of 206 patients in Portugal, a negative correlation was found between magnesium levels and the presence of diabetes. They also found patients with reduced serum magnesium had a significantly greater age and reduced albumin, unlike 
those with increased serum magnesium. In a cross-sectional study of $58 \mathrm{HD}$ patients, a significant negative association was observed between magnesium levels and CRP [50]. Similar findings were illustrated in another study suggesting that low serum magnesium can be a marker for malnutrition [40].

Hence close monitoring of serum magnesium levels, before $\mathrm{HD}$ and even during dialysis, is important to avoid negative outcomes.

\section{Phosphorus and Calcium Disorders}

ESRD is accompanied by profound changes in mineral metabolism. Abnormal mineral metabolism leads to metabolic bone disease [51] and contributes to other clinical problems. Several articles associate hyperphosphatemia, abnormalities in calcium and parathyroid hormone (PTH) levels with increased blood pressure, cardiovascular disease and mortality [11] [52]-[57].

Cardiovascular diseases are one of the most seen causes of death in the HD population and a high level of phosphorus is closely linked to this risk. Hyperphosphatemia causes vascular calcification, coronary atherosclerosis, hyperparathyroidism and smooth muscle proliferation [58]. Lertdumrongluk et al. suggested the link between hyperphosphatemia and increased all-cause and cardiovascular mortality is similar across all age groups, whereas hypophosphatemia is associated with increased mortality only in the elderly HD population [59]. Hence the treatment protocol for phosphorus imbalance should be carefully considered in elderly HD patients other than those belonging to a younger age group. Another study of 12,509 HD patients from the US Renal Data System database by Rubel and Milford showed that serum phosphate greater than 1.62 $\mathrm{mmol} / \mathrm{L}$ was associated with higher risk for a valvular procedure compared with a phosphate level less than $1.62 \mathrm{mmol}$ (HR 1.47; $\mathrm{P}=0.033$ ) [60]. Moreover, Marchais et al. showed that hyperphosphatemia was associated with increased blood pressure, hyperkinetic circulation, increased cardiac work and high arterial tensile stress in a study of MHD patients under 60 years, thus contributing to high cardiovascular morbidity and mortality [52]. A prospective cohort study by $\mathrm{X}$ Huang et al. of HD patients also showed that serum phosphorus is strongly and independently associated with systolic blood pressure and pulse pressure in the early months of dialysis therapy and up to 2 years later [56].

\section{Acid-Base Disorders}

Restoring of the alkali consumed in neutralizing the endogenous acids is one of the aims of HD [61]. Optimal pre-dialysis bicarbonate levels by different entities are summarized in Table 4.

Metabolic acidosis plays an important role in the clinical outcome of MHD patients. Several studies showed that very low levels of serum bicarbonate $(\leq 17$ $\mathrm{mmol} / \mathrm{L})$ as well as very high ones $(>27 \mathrm{mmol} / \mathrm{L})$ contribute to elevated mortality rates in HD patients [15] [18] [66].

In a large cohort study of more than 56,000 patients, in fully adjusted model, $\mathrm{Wu}$ et al. associated acidotic patients with serum bicarbonate less than $22 \mathrm{mmol} / \mathrm{L}$ 
Table 4. Optimal pre-dialysis bicarbonate levels by different entities.

\begin{tabular}{cc}
\hline Guidelines & $\begin{array}{c}\text { Predialysis bicarbonate level } \\
(\mathrm{mmol} / \mathrm{L})\end{array}$ \\
\hline $\begin{array}{c}\text { 2000, 2003 National Kidney Foundation-Kidney Disease } \\
\text { Outcomes Quality Initiative (NFK-KDOQI) [62] [63] }\end{array}$ & $\geq 22$ \\
Dialysis Outcomes and Practice Patterns Study (DOPPS) [15] & $19-22$ \\
2007 European Best Practice Guidelines (EBPG) [64] & $20-22$ \\
2007 Caring for Australasians With Renal Impairment \\
(CARI) [65]
\end{tabular}

with higher death risk [18]. Lowrie et al. found death rates to be higher in patients with serum bicarbonate less than 17.5 or greater than $25 \mathrm{mmol} / \mathrm{L}$ [66]. Also, Bommer et al. associated mid-week predialysis serum bicarbonate $\leq 17 \mathrm{mmol} / \mathrm{L}$ or $>27 \mathrm{mmol} / \mathrm{L}$ with elevated mortality, and the lowest mortality was found to be in the range of $20.1-21.0 \mathrm{mmol} / \mathrm{L}$ [15]. However, another study by Yamamoto et al found no relation between pre- and post-dialysis serum bicarbonate levels and all-cause and cardiovascular mortality [67].

Therefore, it is strongly recommended to continuously evaluate patients' preand post-dialysis serum bicarbonate levels, malnutrition, and inflammation and to adjust bicarbonate dialysate concentration accordingly.

\section{Conclusion}

Electrolytes imbalances and acid-base disorders are frequently encountered complications amongst MHD patients and various factors are important for maintaining their balances. Low levels of sodium, magnesium and high level of phosphate were closely related to poor outcome, while potassium, calcium and bicarbonate showed a $\mathrm{U}$ curve with mortality and are preferred to be controlled in an appropriate range.

There is also an inter-relationship between different serum electrolyte levels. Hyponatremia is associated with hypercalcemia and bone abnormalities. Serum magnesium level is positively related with serum potassium level among HD patients. Phosphate abnormalities are commonly combined with calcium abnormalities. Interaction effects on multiple electrolytes should be considered when targeting on a single one.

Management of electrolytes and fluid balance requires a complex mixture of dialysis therapy, medications, dietary intervention, patient and provider education, communication, and patient adherence. Serum electrolyte levels play a crucial role in the prognosis of MHD patients and further research on their effects and management should be encouraged to ensure that this group of patients is given the best and appropriate care.

\section{References}

[1] El Nahas, A.M. and Bello, A.K. (2005) Chronic Kidney Disease: The Global Chal- 
lenge. The Lancet, 365, 331-340.

[2] Saran, R., Li, Y., Robinson, B., Ayanian, J., Balkrishnan, R., Bragg-Gresham, J., et al. (2015) US Renal Data System 2014 Annual Data Report: Epidemiology of Kidney Disease in the United States. American Journal of Kidney Diseases, 66, S1-S305. https://doi.org/10.1053/j.ajkd.2015.05.001

[3] Wang, S., Chen, R., Liu, Q., Shu, Z., Zhan, S. and Li, L. (2015) Prevalence, Awareness and Treatment of Chronic Kidney Disease among Middle-Aged and Elderly: The China Health and Retirement Longitudinal Study. Nephrology, 20, 474-484. https://doi.org/10.1111/nep.12449

[4] Rhee, C.M., Ravel, V.A., Ayus, J.C., Sim, J.J., Streja, E., Mehrotra, R., et al. (2015) Pre-Dialysis Serum Sodium and Mortality in a National Incident Hemodialysis Cohort. Nephrology Dialysis Transplantation, 1-10.

[5] Waikar, S.S., Curhan, G.C. and Brunelli, S.M. (2011) Mortality Associated with Low Serum Sodium Concentration in Maintenance Hemodialysis. American Journal of Medicine, 124, 77-84.

[6] Hecking, M., Karaboyas, A., Saran, R., Sen, A., Horl, W.H., Pisoni, R.L., et al. (2012) Predialysis Serum Sodium Level, Dialysate Sodium, and Mortality in Maintenance Hemodialysis Patients: the Dialysis Outcomes and Practice Patterns Study (DOPPS). American Journal of Kidney Diseases, 59, 238-248.

https://doi.org/10.1111/nep.12449

[7] Kanbay, M., Goldsmith, D., Uyar, M.E., Turgut, F. and Covic, A. (2010) Magnesium in Chronic Kidney Disease: Challenges and Opportunities. Blood Purification, 29, 280-292.

[8] Yu, L., Li, H. and Wang, S.X. (2017) Serum Magnesium and Mortality in Maintenance Hemodialysis Patients. Blood Purification, 43, 31-36. https://doi.org/10.1159/000451052

[9] Ohya, M., Negi, S., Sakaguchi, T., Koiwa, F., Ando, R., Komatsu, Y., et al. (2014) Significance of Serum Magnesium as an Independent Correlative Factor on the Parathyroid Hormone Level in Uremic Patients. The Journal of Clinical Endocrinology \& Metabolism, 99, 3873-3878. https://doi.org/10.1210/jc.2013-4396

[10] Lacson, E., Wang, W., Ma, L. and Passlick-Deetjen, J. (2015) Serum Magnesium and Mortality in Hemodialysis Patients in the United States: A Cohort Study. American Journal of Kidney Diseases, 66, 1056-1066. https://doi.org/10.1053/j.ajkd.2015.06.014

[11] Young, E.W., Akiba, T., Albert, J.M., McCarthy, J.T., Kerr, P.G., Mendelssohn, D.C., et al. (2004) Magnitude and Impact of Abnormal Mineral Metabolism in Hemodialysis Patients in the Dialysis Outcomes and Practice Patterns Study (DOPPS). American Journal of Kidney Diseases, 44, 34-38.

[12] Nakai, S., Akiba, T., Kazama, J., Yokoyama, K., Fukagawa, M., Tominaga, Y., et al. (2008) Effects of Serum Calcium, Phosphorous, and Intact Parathyroid Hormone Levels on Survival in Chronic Hemodialysis Patients in Japan. Therapeutic Apheresis and Dialysis, 12, 49-54. https://doi.org/10.1111/j.1744-9987.2007.00540.x

[13] Miller, J.E., Kovesdy, CP., Norris, K.C., Mehrotra, R., Nissenson, A.R., Kopple, J.D., et al. (2010) Association of Cumulatively Low or High Serum Calcium Levels with Mortality in Long-Term Hemodialysis Patients. American Journal of Nephrology, 32, 403-413. https://doi.org/10.1159/000319861

[14] Rivara, M.B., Ravel, V., Kalantar-Zadeh, K., Streja, E., Lau, W.L., Nissenson, A.R., et al. (2015) Uncorrected and Albumin-Corrected Calcium, Phosphorus, and Mortality in Patients Undergoing Maintenance Dialysis. Journal of the American Society of Nephrology, 26, 1671-1681. https://doi.org/10.1681/asn.2014050472 
[15] Bommer, J., Locatelli, F., Satayathum, S., Keen, M.L., Goodkin, D.A., Saito, A., et al. (2004) Association of Predialysis Serum Bicarbonate Levels with Risk of Mortality and Hospitalization in the Dialysis Outcomes and Practice Patterns Study (DOPPS). American Journal of Kidney Diseases, 44, 661-671.

[16] Kovesdy, C.P., Regidor, D.L., Mehrotra, R., et al. (2007) Serum and Dialysate Potassium Concentrations and Survival in Hemodialysis Patients. Clinical Journal of the American Society of Nephrology, 2, 999-1007. https://doi.org/10.2215/CJN.04451206

[17] Sakaguchi, Y., Fujii, N., Shoji, T., Hayashi, T., Rakugi, H., Iseki, K., et al. (2014) Magnesium Modifies the Cardiovascular Mortality Risk Associated with Hyperphosphatemia in Patients Undergoing Hemodialysis: A Cohort Study. PLoS ONE, 9, e116273. https://doi.org/10.1371/journal.pone.0116273

[18] Wu, D.Y., Shinaberger, C.S., Regidor, D.L., McAllister, C.J., Kopple, J.D. and Kalantar-Zadeh, K. (2006) Association between Serum Bicarbonate and Death in Hemodialysis Patients: Is It Better to be Acidotic or Alkalotic? Clinical Journal of the American Society of Nephrology, 1, 70-78. https://doi.org/10.2215/CJN.00010505

[19] Santos Sergio, F.F. and Peixoto, A.J. (2010) Sodium Balance in Maintenance Hemodialysis. Seminars in Dialysis, 23, 549-555.

https://doi.org/10.1111/j.1525-139X.2010.00794.x

[20] Mandai, S., Kuwahara, M., Kasagi, Y., Kusaka, K., Tanaka, T., Shikuma, S., Akita, W. and Sasaki, S. (2013) Lower Serum Sodium Level Predicts Higher Risk of Infection-Related Hospitalization in Maintenance Hemodialysis Patients: An Observational Cohort Study. BMC Nephrology, 14, 276. https://doi.org/10.1186/1471-2369-14-276

[21] McCausland, F.R., Brunelli, S.M. and Waikar, S.S. (2012) Dialysate Sodium, Serum Sodium and Mortality in Maintenance Hemodialysis. Nephrology Dialysis Transplantation, 27, 1613-1618. https://doi.org/10.1093/ndt/gfr497

[22] Nigwekar, S.U., Wenger, J., Thadhani, R. and Bhan, I. (2013) Hyponatremia, Mineral Metabolism, and Mortality in Incident Maintenance Hemodialysis Patients: A Cohort Study. American Journal of Kidney Diseases, 62, 755-762. https://doi.org/10.1053/j.ajkd.2013.02.367

[23] Meira, et al. (2007) Influence of Sodium Profile in Preventing Complications during Hemodialysis. Hemodialysis International, 11, S29-S32. https://doi.org/10.1111/j.1542-4758.2007.00226.x

[24] Rodrigues Telini, L.S., de Carvalho Beduschi, G., Caramori, J.C., Castro, J.H., Martin, L.C. and Barretti, P. (2014) Effect of Dietary Sodium Restriction on Body Water, Blood Pressure, and Inflammation in Hemodialysis Patients: A Prospective Randomized Controlled Study. International Urology and Nephrology, 46, 91-97. https://doi.org/10.1111/j.1525-139X.2010.00794.x

[25] Poulikakos, D., Banerjee, D. and Malik, M. (2014) Risk of Sudden Cardiac Death in Chronic Kidney Disease. Journal of Cardiovascular Electrophysiology, 25, 222-231. https://doi.org/10.1111/jce.12328

[26] Jadoul, M., Thumma, J., Fuller, D.S., Tentori, F., Li, Y., Morgenstern, H., et al. (2012) Modifiable Practices Associated with Sudden Death among Hemodialysis Patients in the Dialysis Outcomes and Practice Patterns Study. Clinical Journal of the American Society of Nephrology, 7, 765-774.

https://doi.org/10.2215/CJN.08850811

[27] Pun, P.H., Lehrich, R.W., Honeycutt, E.F., Herzog, C.A. and Middleton, J.P. (2011) Modifiable Risk Factors Associated with Sudden Cardiac Arrest within Hemodialysis Clinics. Kidney International, 79, 218-227. https://doi.org/10.1038/ki.2010.315 
[28] Nie, Y., Zou, J., Liang, Y., Shen, B., Liu, Z., Cao, X., et al. (2016) Electrocardiographic Abnormalities and QTc Interval in Patients Undergoing Hemodialysis. PLoS ONE, 11, e0155445. https://doi.org/10.1371/journal.pone.0155445

[29] Genovesi, S., Valsecchi, M.G., Rossi, E., Pogliani, D., Acquistapace, I., De Cristofaro, V., et al. (2009) Sudden Death and Associated Factors in a Historical Cohort of Chronic Haemodialysis Patients. Nephrology Dialysis Transplantation, 24, 2529 2536. https://doi.org/10.1093/ndt/gfp104

[30] Hwang, J.C., Jiang, M.Y. and Wang, C.T. (2013) Lower Serum Potassium Combined with Lower Sodium Concentrations Predict Long-Term Mortality Risk in Hemodialysis Patients. BMC Nephrology, 14, 269. https://doi.org/10.1186/1471-2369-14-269

[31] Yetkin, E., Ileri, M., Tandog `an, I., et al. (2000) Increased QT Interval Dispersion after Hemodialysis: Role of Peridialytic Electrolyte Gradients. Angiology, 51, 499 504. https://doi.org/10.1177/000331970005100607

[32] Burton, J.O., Grundy, B.J. and McIntyre, C.W. (2008) Hemodialysis-Induced Left Ventricular Dysfunction Is Associated with an Increase in Ventricular Arrhythmias. Renal Failure, 30, 701-709. https://doi.org/10.1080/08860220802212908

[33] Saravanan, P. and Davidson, N.C. (2010) Risk Assessment for Sudden Cardiac Death in Dialysis Patients. Circulation: Arrhythmia and Electrophysiology, 3, $553-$ 559. https://doi.org/10.1161/CIRCEP.110.937888

[34] Pun, P.H. (2014) The Interplay between CKD, Sudden Cardiac Death, and Ventricular Arrhythmias. Advances in Chronic Kidney Disease, 21, 480-488. https://doi.org/10.1053/j.ackd.2014.06.007

[35] Morris, S.T., Stewart, G.A., Rodger, R.S. and Jardine, A.G. (1999) QT Dispersion before and after Hemodialysis. Journal of the American Society of Nephrology, 10, 160-163.

[36] Elsharkawy Magdy, M., Youssef, A.M. and Zayoon, M.Y. (2006) Intradialytic Changes of Serum Magnesium and Their Relation to Hypotensive Episodes in Hemodialysis Patients on Different Dialysates. Hemodialysis International, 10, S16S23. https://doi.org/10.1111/j.1542-4758.2006.00120.x

[37] Ishimura, E., Okuno, S., Yamakawa, T., Inaba, M. and Nishizawa, Y. (2007) Serum Magnesium Concentration Is a Significant Predictor of Mortality in Maintenance Hemodialysis Patients. Magnesium Research, 20, 237-244.

[38] Joao Matias, P., Azevedo, A., Laranjinha, I., Navarro, D., Mendes, M., Ferreira, C., et al. (2014) Lower Serum Magnesium Is Associated with Cardiovascular Risk Factors and Mortality in Haemodialysis Patients. Blood Purification, 38, 244-252. https://doi.org/10.1159/000366124

[39] De Roij van Zuijdewijn, C.L., Grooteman, M.P., Bots, M.L., Blankestijn, P.J., Steppan, S., Buchel, J., et al. (2015) Serum Magnesium and Sudden Death in European Hemodialysis Patients. PLoS ONE, 10, e0143104. https://doi.org/10.1371/journal.pone.0143104

[40] Kurita, N., Akizawa, T., Fukagawa, M., Onishi, Y., Kurokawa, K. and Fukuhara, S. (2015) Contribution of Dysregulated Serum Magnesium to Mortality in Hemodialysis Patients with Secondary Hyperparathyroidism: A 3-Year Cohort Study. Clinical Kidney Journal, 8, 744-752. https://doi.org/10.1093/ckj/sfv097

[41] Pakfetrat, M., Roozbeh Shahroodi, J., Malekmakan, L., Zare, N., Hashemi Nasab, M. and Hossein Nikoo, M. (2010) Is There an Association between Intradialytic Hypotension and Serum Magnesium Changes? Hemodialysis International, 14, 492-497. https://doi.org/10.1111/j.1542-4758.2010.00477.x 
[42] Liu, F., Zhang, X., Qi, H., Wang, J., Wang, M., Zhang, Y., Yan, H. and Zhuang, S. (2013) Correlation of Serum Magnesium with Cardiovascular Risk Factors in Maintenance Hemodialysis Patients-A Cross-Sectional Study. Magnesium Research, 26, 100-108.

[43] Tzanakis, I.P.A., Kounali, D., et al. (1997) Mitral Annular Calcifications in Haemodialysis Patients: A Possible Protective Role of Magnesium. Nephrology Dialysis Transplantation, 12, 2036-2037. https://doi.org/10.1093/ndt/12.9.2036

[44] Meema, H.E., Oreopoulous, D.G. and Rapoport, A. (1987) Serum Magnesium Level and Arterial Calcification in End-Stage Renal Disease. Kidney International, 32, 388-394. https://doi.org/10.1038/ki.1987.222

[45] Dousdampanis, P., Trigka, K. and Fourtounas, C. (2014) Hypomagnesemia, Chronic Kidney Disease and Cardiovascular Mortality: Pronounced Association But Unproven Causation. Hemodialysis International, 18, 730-739.

https://doi.org/10.1111/hdi.12159

[46] Nasri, H. and Baradavan, A. (2004) Correlation of Serum Magnesium with Dyslipidemia in Maintenance Hemodialysis Patients. Acta Medica (Hradec Kralove), 47, 263-265.

[47] Robles, N.R., Escola, J.M., Albarran, L. and Espada, R. (1998) Correlation of Serum Magnesium and Serum Lipid Levels in Hemodialysis Patients. Nephron, 78, 118 119. https://doi.org/10.1159/000044895

[48] Ansari, M.R., Maheshwari, N., Shaikh, M.A., Laghari, M.S., Darshana, L.K. and Ahmed, K. (2012) Correlation of Serum Magnesium with Dyslipidemia in Patients on Maintenance Hemodialysis. Saudi Journal of Kidney Diseases and Transplantation, 23, 21-25.

[49] Khatami, M.R., Mirchi, E., Khazaeipour, Z., Abdollahi, A. and Jahanmardi, A. (2013) Association between Serum Magnesium and Risk Factors of Cardiovascular Disease in Hemodialysis Patients. Iranian Journal of Kidney Diseases, 7, 47-52.

[50] Pakfetrat, M., Malekmakan, L., Roozbeh, J. and Haghpanah, S. (2008) Magnesium and Its Relationship to C-Reactive Protein among Hemodialysis Patients. Magnesium Research, 21, 167-170.

[51] Atsumi, K., Kushida, K., Yamazaki, K., Shimizu, S., Ohmura, A. and Inoue, T. (1999) Risk Factors for Vertebral Fractures in Renal Osteodystrophy. American Journal of Kidney Diseases, 33, 287-293.

[52] Marchais, S.J., Metivier, F., Guerin, A.P. and London, G.M. (1999) Association of Hyperphosphataemia with Haemodynamic Disturbances in End-Stage Renal Disease. Nephrology Dialysis Transplantation, 14, 2178-2183. https://doi.org/10.1093/ndt/14.9.2178

[53] Rodriguez-Benot, A., Martin-Malo, A., Alvarez-Lara, M.A., Rodriguez, M. and Aljama, P. (2005) Mild Hyperphosphatemia and Mortality in Hemodialysis Patients. American Journal of Kidney Diseases, 46, 68-77. https://doi.org/10.1053/j.ajkd.2005.04.006

[54] Lindsay, R.M., Alhejaili, F., Nesrallah, G., Leitch, R., Clement, L., Heidenheim, A.P. and Kortas, C. (2003) Calcium and Phosphate Balance with Quotidian Hemodialysis. American Journal of Kidney Diseases, 42, 24-29.

[55] Waheed, A.A., Pedraza, F., Lenz, O. and Isakova, T. (2013) Phosphate Control in End-Stage Renal Disease: Barriers and Opportunities. Nephrology Dialysis Transplantation, 28, 2961-2968. https://doi.org/10.1093/ndt/gft244

[56] Huang, C.X., Plantinga, L.C., Fink, N.E., Melamed, M.L., Coresh, J. and Powe, N.R. (2008) Phosphate Levels and Blood Pressure in Incident Hemodialysis Patients: A 
Longitudinal Study. Advances in Chronic Kidney Disease, 15, 321-331. https://doi.org/10.1053/j.ackd.2008.04.012

[57] Blayney, M.J. and Tentori, F. (2009) Trends and Consequences of Mineral Bone Disorder in Haemodialysis Patients: Lessons from the Dialysis Outcomes and Practice Patterns Study (DOPPS). Journal of Renal Care, 35, 7-13. https://doi.org/10.1111/j.1755-6686.2009.00048.x

[58] Schwarz, U. (2000) Morphology of Coronary Atherosclerotic Lesions in Patients with End-Stage Renal Failure. Nephrology Dialysis Transplantation, 15, 218-233. https://doi.org/10.1093/ndt/15.2.218

[59] Lertdumrongluk, P., Rhee, C.M., Park, J., Lau, W.L., Moradi, H., Jing, J., et al. (2013) Association of Serum Phosphorus Concentration with Mortality in Elderly and Nonelderly Hemodialysis Patients. Journal of Renal Nutrition, 23, 411-421. https://doi.org/10.1053/j.jrn.2013.01.018

[60] Rubel, J.R. and Milford, E.L. (2003) The Relationship between Serum Calcium and Phosphate Levels and Cardiac Valvular Procedures in the Hemodialysis Population. American Journal of Kidney Diseases, 41, 411-421. https://doi.org/10.1053/ajkd.2003.50050

[61] Zuchelli, P. and Santaro, A. (1993) Correction of Acid-Base Balance by Dialysis. Kidney International, 43, 179-183.

[62] National Kidney Foundation (2001) K/DOQI Clinical Practice Guidelines for Nutrition in Chronic Renal Failure. American Journal of Kidney Diseases, 36, S1-S140.

[63] National Kidney Foundation (2003) K/DOQI Clinical Practice Guidelines for Bone Metabolism and Disease in Chronic Kidney Disease. American Journal of Kidney Diseases, 42, S1-S201.

[64] Fouque, D., Vennegoor, M., ter Wee, P., Wanner, C., Basci, A., et al. (2007) EBPG Guideline on Nutrition. Nephrology Dialysis Transplantation, 22, ii45-ii87. https://doi.org/10.1093/ndt/gfm020

[65] Voss, D., Hodson, E. and Crompton, C. (2007) Nutrition and Growth in Kidney Disease: CARI Guidelines. Australian Family Physician, 36, 253-254.

[66] Lowrie, E.G. and Lew, N. (1990) Death Risk in Hemodialysis Patients: The Predictive Value of Commonly Measured Variables and an Evaluation of Death Rate Differences between Facilities. American Journal of Kidney Diseases, 15, 458-482.

[67] Yamamoto, T., Shoji, S., Yamakawa, T., Wada, A., Suzuki, K., Iseki, K., et al. (2015) Predialysis and Postdialysis $\mathrm{pH}$ and Bicarbonate and Risk of All-Cause and Cardiovascular Mortality in Long-term Hemodialysis Patients. American Journal of Kidney Diseases, 66, 469-478. https://doi.org/10.1053/j.ajkd.2015.04.014 


\section{Abbreviations}

$\begin{array}{ll}\text { AOR } & \text { Adjusted odds ratio } \\ \text { CARI } & \text { Caring for Australasians With Renal Impairment } \\ \text { CI } & \text { Confidence interval } \\ \text { CKD } & \text { Chronic kidney disease } \\ \text { DOPPS } & \text { Dialysis Outcomes and Practice Patterns Study } \\ \text { EBPG } & \text { European Best Practice Guidelines } \\ \text { ECG } & \text { Electrocardiogram } \\ \text { ESRD } & \text { End-stage renal disease } \\ \text { HD } & \text { Hemodialysis } \\ \text { HR } & \text { Hazard risk } \\ \text { hs-CRP } & \text { High sensitivity C-reactive protein } \\ \text { K } & \text { Potassium } \\ \text { Mg } & \text { Magnesium } \\ \text { MHD } & \text { Maintenance hemodialysis } \\ \text { NFK-KDOQI National Kidney Foundation-Kidney Disease Outcomes Quality } \\ \text { Initiative } & \\ \text { nPCR } & \text { Normalized protein catabolic rate } \\ \text { PTH } & \text { Parathyroid hormone } \\ \text { RRT } & \text { Renal replacement therapy } \\ \text { SHPT } & \text { Secondary hyperparathyroidism } \\ \text { USRDS } & \text { US Renal Data System }\end{array}$

Submit or recommend next manuscript to OALib Journal and we will provide best service for you:

- Publication frequency: Monthly

- 9 subject areas of science, technology and medicine

- Fair and rigorous peer-review system

- Fast publication process

- Article promotion in various social networking sites (LinkedIn, Facebook, Twitter, etc.)

- Maximum dissemination of your research work

Submit Your Paper Online: Click Here to Submit

Or Contact service@oalib.com 